\title{
Religious Diversity and Disagreement
}

\author{
Matthew A. Benton
}

\section{Introduction}

Where liberal societies provide freedoms concerning speech, religious belief, or other matters of personal conscience, disagreement inevitably follows. Yet even where disagreement reigns, there is no shortage of confidence on any side.

To some philosophers, confidence in the face of disagreement is at worst irrational and dubiously dogmatic; and at best, such confidence may only be had by conscientiously reckoning with the fact that a great many highly intelligent and well-read individuals-people whom one would regard as at least one's intellectual peers-have reached opposing conclusions. How one must reckon with such disagreement is hotly debated among epistemologists. I don't intend to settle such matters here. This essay offers an overview of how philosophers have approached problems of disagreement, with a special focus on religious diversity and disagreement. By the end I shall discuss some novel considerations that seem distinctive of religious inquiry, and which complicate the application of prominent views in the epistemology of disagreement.

\section{Epistemological Puzzles of Disagreement}

Disagreement has received a great deal of recent attention in mainstream epistemology. ${ }^{1}$ Yet the main questions were originally posed by philoso-

\footnotetext{
${ }^{1}$ See especially Feldman and Warfield 2010; Christensen and Lackey 2013, and the Ferrari and Pedersen chapter in this volume.
} 
phers who had their eye on the significance of religious disagreement (see Gutting 1982; van Inwagen 1994, 41-46 and 1996, 139; Plantinga 1995; Rosen 2001, 83-87). We will first survey some issues raised by disagreement, and then in $\S_{3}$ consider more explicit applications to religious (and atheist) belief.

Why should disagreement matter to how we think about epistemology? First, notice our general tendency to reconsider our beliefs when we discover that others disagree. In particular, when we regard our interlocutors as being as being our peers-as well-informed as we, and of similar intelligence (and not joking with us) - then learning that they disagree often results in our suspending judgment on the matter. Similar results apply when we move from full belief, disbelief, and suspension of belief, to finer-grained doxastic states like degrees of belief or subjective probabilities, sometimes called credences: if you have a 0.9 credence that it will rain today in our area, whereas I have only 0.3 credence that it will rain today, and we both updated on evidence from what we regard as equally reliable sources about the weather, you will likely lower your credence from 0.9 (and I will likely raise mine from 0.3). ${ }^{2}$ Or consider David Christensen's check-splitting case $(2007,193)$ : we go to dinner, and we agreed to split the check evenly, adding a $20 \%$ tip. We each mentally calculate our share, and I become highly confident that our shares are $\$ 43$, whereas you become highly confident that we each owe $\$ 45$. How should we react to each other's beliefs? Presumably we will each lower our confidence, and rethink our calculations, since either (or both of us) may have made a mistake. Similar cases can be given about perceptual judgments rather than mental reasoning, for example, that you and your friend each see the end of a horse race, from nearly identical viewing points, but you disagree about which horse won (Kelly 2010, 113).

For some philosophers, what we typically do in these disagreements is thought to be indicative of what we ought to do if we are to be rational: we ought, in such cases, be conciliatory to our peer by reducing our con-

\footnotetext{
${ }^{2}$ Hereafter, unless otherwise stated, I shall use "belief" as a catch-all to refer to both full and partial belief, such that "lowering" one's confidence can mean either dropping one's full belief in favor or suspending judgment, or reducing one's credence.
} 
fidence in our initial conclusion, by suspending judgment or shifting credence toward the peer's. The normative principles behind why we ought to do this, according to these Strong Conciliationists, can vary. Some endorse an "Equal Weight" view, according to which one must grant equal evidential weight to my peer's opinion as I do to my own. ${ }^{3}$

Many think that implicit in such views is the idea that a set of evidence only supports one doxastic response. ${ }^{4}$ Consider the principle Uniqueness:

Uniqueness Given one's total evidence, there is a unique rational doxastic attitude that one can take to any proposition. ${ }^{5}$

If Uniqueness is false, there is room for thinking that there could be reasonable disagreements, even among peers who have the same evidence. Denying Uniqueness amounts to endorsing a permissive view of what rationality requires, such that one's evidence may rationally support more than one doxastic position. Thus one might be what White (2005) calls a radical permissivist, by thinking that, at least in some circumstances, one's total evidence can permit either believing that $p$ or believing that $\neg p$. But if rationality were that permissive, it is hard to see why disagreement would ever put pressure on us: for people even with identical evidence could reasonably disagree, on the grounds that said evidence can reasonably support believing either way. Less controversially, one might be a moderate permissivist by denying this radical view yet insisting that, at least in some circumstances, one's total evidence can permit, say, either believing that $p$ or suspending judgment on $p$. More moderate still would be a view that denies each of the above concerning outright belief and withholding belief, but allows that in some circumstances, one's evidence at least makes rational a (perhaps small) range of credences (Schoenfield 2014).

Perhaps conciliatory pressure is due to the idea that learning of a peer's differing response gives you new evidence, higher-order evidence, which

3See Elga 2007, Christensen 2007, and Cohen 2013.

${ }^{4}$ However, see Christensen 2016, who argues that Conciliationism can be motivated even without Uniqueness.

5White 2005, 445, and Feldman 2007, 205. 
bears on how well you handled the initial evidence. Feldman insisted that learning of a peer's reaching a different conclusion, on the basis of the same evidence, amounts to evidence against one's own conclusion because "evidence that there is evidence that $p$ is evidence for $p$ " (Feldman 2006,208 ). Such a principle says that discovering that a peer concludes differently on the basis of the same evidence E provides new higher-order evidence that I have misconstrued what E supports. More specifically, Feldman recently argues for

EEE3 If $\mathrm{S}$ has evidence, E1, supporting the proposition that there is someone who has evidence that supports $p$, then $\mathrm{S}$ has some evidence, E2, that supports p. $(2014,292)$

Such a principle could explain why it often seems we ought to reduce our confidence in such situations. However, $\mathrm{EEE}_{3}$ cannot be correct. Suppose your friend Joe is to guess which one of three objects you are about to put into an empty box: an apple, a ball, or some cheese. Out of his sight, you put in the apple; so you, but not he, know that there is an apple in the box. You then tell Joe that it isn't a ball in the box. Given what Joe knows about the setup, your testimony provides Joe with some evidence there is cheese in the box, because Joe's learning that it's not a ball raises the probability for him that it's cheese in the box. As the antecedent of $\mathrm{EEE}_{3}$ has it, you have evidence (E1) that there is someone (Joe) who has evidence which supports $(p)$ that there is cheese in the box; but because you know there is no cheese in the box, your knowing E1 is not, for you, evidence supporting that there is cheese inside. (If it were, then by merely telling Joe that what you put in the box isn't a ball, you thereby would have acquired some additional evidence that you didn't put in an apple. But that's absurd.) So $\mathrm{EEE}_{3}$ is false. ${ }^{6}$

Principles like Uniqueness or $\mathrm{EEE}_{3}$ appeal to one's evidence without stipulating exactly what evidence is or what it takes to "have" it.7 Notice

\footnotetext{
${ }^{6}$ Note that Feldman's replies to objections to $\mathrm{EEE}_{3}(2014,296-299)$ don't apply to this case. See Fitelson 2012 for a refutation of Feldman's earlier slogan, which also casts doubt on $\mathrm{EEE}_{3}$.

${ }^{7}$ As Hawthorne and Srinivasan 2013 point out, if one takes a highly externalist view
} 
that one's background beliefs (or one's prior probability function), while not typically deemed a part of the relevant evidence, plays a crucial role in how one rationally updates on new evidence to arrive at one's beliefs. For example, if you and I both hear the same testimony from John that he has bought a new sportscar, you might believe him while I-since I also believe it is April Fools' Day-do not believe him. If we don't count my background belief about the date as part of the evidence, then clearly, it can be reasonable for us to have different doxastic responses to the same (testimonial) evidence. Similarly, much depends here on what it takes for us to possess the "same evidence". Suppose we just consider propositions as used in a deductive argument: do two individuals who disagree on what to conclude from it (one infers by modus ponens, the other by modus tollens) count as "having the same evidence"? Is it possible to have some $p$ as evidence when you dismiss it as false? Does one have perceptual evidence when one believes one has just taken a hallucinogen?

Apart from such principles about evidence, some appeal explicitly to the notion of an epistemic defeater to suggest that the nature of certain disagreements defeats the justification one might need in order to know, or even acceptably believe, one's views (Goldberg 2013, 2014, 2015). On such an approach, acknowledging that certain peer disagreements are systematic presents one with a defeater for the justification one might have for one's belief. Systematic disagreements are (i) widespread, (ii) entrenched, and (iii) non-localized, i.e., involving many related matters rather than the dispute being only over a particular local proposition. Such defeaters are not easily dispensed with (e.g., by defeating them with some other evidence which would defeat the defeater), because such disagreements induce the concern that even those who are believe truly were somehow lucky to arrive at the truth. Given this, systematic disagreements seem to rob one's beliefs of justification. ${ }^{8}$

But matters are rarely as clean-cut as the idealized cases to which Con-

of evidence, such as Williamson's (2000, Ch. 9) $\mathrm{E}=\mathrm{K}$ view, the problems concerning disagreement looks quite different.

${ }^{8}$ Though widely used in epistemology, the viability of defeat in epistemology has come under challenge: see Lasonen-Aarnio 2010, Hawthorne and Srinivasan 2013, and Baker-Hytch and Benton 2015. 
ciliationists appeal. In how many cases do we actually have the exact same evidence as our interlocutor? Or similarly, how often is one's disagreeing interlocutor really thought to be intellectual peer (King 2012)? These and similar worries have led many to think that there just is nothing general to be said about what one should do when one faces disagreements even with one's peers (see Hawthorne and Srinivasan 2013, and Matheson 2014).

Many have criticized the blanket way in which some Conciliationists have aimed to offer a universal principle of rationality which would cover all the relevant cases. A common objection is that (unrestricted) Conciliationism is self-undermining: many philosophers, who presumably regard each other as peers and consider all the same arguments, disagree over the truth of (unrestricted) Conciliationism. So by the (unrestricted) Conciliationist's lights, one should not be very confident in their own view (see Elga 2010; cf. Pittard 2015b for a way out).

Kelly $(2005,2010,2011)$ raises several concerns with versions of Conciliationism, even for idealized cases. One worry is that deferring to one's peer by reducing one's confidence amounts to an illicit double-counting of the evidence. Suppose we each begin with the same grounds E bearing on whether $p$; and we disclose that I've concluded $p$ whereas you, $\neg p$. My treating your contrary belief, reached from your evaluation of $\mathrm{E}$, as an added reason to believe $\neg p$ is to allow $\mathrm{E}$ to have additional evidential weight (processed through you) beyond what I've already given it. And somewhat awkwardly, in doing this, I would be treating the fact that you believe $\neg p$ on the basis of $\mathrm{E}$, as a reason for me to believe $\neg p$ even though you wouldn't yourself regard your believing that $\neg p$ as an additional reason—on top of E-for believing $\neg p$ (Kelly 2005, $187 \mathrm{ff}$.). But if it would be illicit for you to use the fact that you believe it as further reason to believe it, why should it be okay for me to do this?

Another worry is that doing what the Equal Weight view requires can lead one away from the rational attitude required by Uniqueness. Suppose there is a fact about the degree to which evidence E supports $p$, namely, that it makes $p$ o.8 probable. Upon evaluating E, your credence in $p$ is, quite rightly, o.8, whereas I quite unreasonably arrive at a credence of 0.2 . In such a case you have fulfilled the uniquely rational doxastic attitude 
given E. But when we meet and discuss our evidence and our conflicting credences, the Equal Weight view requires that you must, to be rational, split the difference with me and we must both then be 0.5 confident in $p$. But to do this would be for you to depart from the uniquely rational attitude toward $p$ given E. Thus the Equal Weight view results in making the original $\mathrm{E}$ irrelevant to the bearing of our new evidence (which includes $\mathrm{E}$ but also includes the facts about what credences we had reached upon consulting E) on $p$; the actual evidence bearing on $p$ gets completely swamped by psychological facts about what the two of us believe (Kelly 2010, 123-124).

There is something to be said for the idea that the one who has in fact reasoned properly to the conclusion supported by the evidence (even if that conclusion is that the evidence supports suspending judgment), may sometimes remain steadfast, and rationally so, in her doxastic position; it is, after all, the one who has made a mistake who should revise their position. 9 If something like this is correct, then what one ought to do in cases of disagreement is not independent of who has rightly handled the evidence. "Steadfasters" like Kelly want to insist that what Conciliationism gets wrong is that each party in a disagreement owes the same belief revision regardless of who is closer to the truth. Indeed, one might draw on the defeater epistemology of disagreement to argue that, in a case of peer disagreement, those who reasoned imperfectly from the evidence are most plausibly the ones whose justification is defeated: for if there is some fact about how they evaluated the evidence that they should have understood, which if apprised of would lead them to change their beliefs, that fact seems like a good candidate for generating defeaters. ${ }^{10}$

Though epistemologists working on disagreement have considered abstract and highly idealized cases, the issues they raise provide the backdrop for turning to matters raised by religious disagreement.

\footnotetext{
${ }^{9}$ The trouble, of course, is that from within the disagreer's perspective, one cannot tell who that is.

${ }^{10}$ For an account of evidence one should have had, and how it might issue in normative defeaters, see Goldberg 2016; for criticisms, see Benton 2016.
} 


\section{Religious Disagreement}

Religion is a controversial domain: religions distinguish themselves by making various claims about the supernatural, humanity, and how to live. Even among religious adherents who share certain core religious commitments, there remains much disagreement between sects or denominations over doctrine, worship, spirituality, the afterlife, and so on. Contributing to this diversity are the many non-religious or irreligious, particularly atheists, who think that nearly all positive claims (at least about the existence of the supernatural) are false. For simplicity's sake, we shall focus on the basic positions of the theist, ${ }^{11}$ atheist, and agnostic, though it should be clear that the structural issues may extend to diversity between religions (or atheisms). ${ }^{12}$

Complicating matters are concerns about what counts as evidence in the religious domain, whether some forms of evidence are more probative than others, and whether one must grant more weight to public or shared evidence. For example, philosophical arguments often present themselves as publically available and neutral reasoning about, say, whether there is a God, whereas those who appeal to religious experience (Alston 1991) as a kind of evidence for God typically conceive of such evidence as inherently private. Testimony from trusted individuals, or from an entire tradition (cf. Zagzebski 2012), can form another kind of ground for belief or disbelief, and it may be that such testimony can ground religious beliefs even in the midst of religious diversity (Baker-Hytch 2018). But the epistemic force of that testimony may depend whether the testifier functions as an authority or as a kind of expert advisor (see Lackey 2018). Moreover, most reflective individuals will weight the value of these distinct grounds in different ways. Finally, there is plausibly no dispute-independent standard of the epistemic credentials by which one might be judged a "peer": philosophical atheists may think that only one's capacity for intellectual reasoning matters, whereas certain religious views claim, say, that purity

\footnotetext{
${ }^{11} \mathrm{By}$ 'theist' I mean to be as broad as possible: someone who thinks that an extremely powerful, extremely knowledgeable, and extremely benevolent being exists.

${ }^{12}$ For helpful overviews of epistemological issues arising from religious disagreement, see King 2008 and Pittard 2015 a.
} 
of heart or selfless love for others is a precondition of learning the truth about God (see esp. Pittard 2015a, §4). Thus even if there were consensus on what kind of evidence in the religious domain is most probative, there is no dispute-neutral way of assessing which epistemic credentials one must have in order to properly assess that evidence. ${ }^{13}$

Notice that these complications arise even on the assumption that Uniqueness (discussed in \$2 above), or some other strong Conciliationist principle, is true. For these complications make it difficult, in matters of religion, to discern what one's total evidence actually is. Even if it is possible to establish in what one's total evidence consists, related complications involve which bits of evidence are most probative and so are to be given most weight, and so what religious propositions that total evidence in fact supports. And even if these matters are settled to everyone's satisfaction, other difficulties loom for whom is to count as a "peer" or as an epistemic "superior"; and if properly settling the above matters depends on regarding only the right individuals as peers or superiors, then it should be clear that there are many choice-points where things can go wrong, and there will even be disagreement, at each juncture, over which way of settling matters is wrong. As such, reaching agreement over Uniqueness, or between Conciliationists and Steadfasters, will not necessarily help us discern what is required in the face of religious disagreement.

Yet there are some for whom the mere fact of religious disagreement plausibly recommends reconsideration of their position. For the complacent theist (or atheist or agnostic), who acquired their view prereflectively "at mother's knee" and did not consider the reasons why their position is correct, acknowledging the existence of disagreement should presumably cause them rethink their position. Rosen $(2001,85)$ has in mind the complacent theist who takes himself upon reflection to have no positive grounds for his belief: "no arguments, no compelling authority, and most importantly, nothing that he would regard as direct experience of the divine: a theist who believes simply because he has been immersed in a cul-

\footnotetext{
${ }^{13}$ This problem may extend to proposals on which what matters isn't having the same evidence, but rather that one should judge another a peer when they are (roughly) as justified, given their evidence, in holding their religious beliefs: see Lackey 2014.
} 
ture in which God's existence is taken for granted." Though Rosen thinks it may be rationally permissible for even such a complacent theist to persist simply as an act of faith, Rosen nevertheless thinks that he "probably should reconsider when he realizes that this commitment is an accident of history," and that "there is something admirable in the choice to reconsider." Though Rosen does not consider the comparably situated atheist or agnostic, presumably similar thoughts apply. But we can go further than Rosen; for there are those who complacently hold their view on the basis of reasons they regard as compelling, though they've never really considered arguments to the contrary. For the (a)theist who thinks she has compelling grounds, yet who never bothered to consider others' beliefs or the reasons one might think differently, the existence of many who disagree on the basis of different grounds should, if acknowledged, induce one to reconsider. For acknowledging such disagreements involves learning that others have different grounds which one might find compelling, if only one would give them an honest hearing. ${ }^{14}$

Complacency aside, let us focus on those more reflective individuals whose beliefs, at least on matters of religion, were (or are being) formed while engaged with many differing perspectives and arguments. (In virtue of reading this, I shall assume you are one of them.) For reflective individuals, it may be that recognizing the extent of disagreement about religious issues will sometimes put pressure on them to lower their confidence, pushing them toward agnosticism. Indeed, a natural thought is that the greater the diversity, the more that one should feel an epistemological problem with holding one's own views. ${ }^{15}$ But as noted earlier, whether it does (or must) will depend on specific factors concerning what

${ }^{14}$ What is the status of their beliefs before they've acknowledged disagreement in this way? Much depends here on one's theory of knowledge. Some will want to say that their beliefs lack "justification" until they've reckoned with the disagreement and rationally assessed grounds for opposing views; still others will insist that even if "justified" and true, such beliefs aren't yet knowledge. I don't have settled views on this, though I'm enough of an externalist to be open to the idea that such beliefs could be "unreasonable" knowledge in Lasonen-Aarnio's (2010) sense.

${ }^{15}$ But see White 2018 for a challenge to the idea that if there is an epistemological problem of the diversity of opinion, it only gets worse in a larger universe with more diversity. 
counts as evidence, how to weigh evidence and expertise more generally, and how charitable one has been to opposing views. Given these complications, and that settling such matters can depend on disputed views in epistemology, I am pessimistic that there can be any general epistemic obligations arising from acknowledging the fact religious disagreement.

One question that arises is whether the great range of religious diversity, between religions and within religions, provides a kind of support for a particular take on how one's own religious view relates to the others. Hick (2004) contends that such diversity supports a pluralism on which a divine being of some kind is the revelatory source of all religions, but where the revelatory process necessarily involves cultural reception which influences how different groups adopt and interpret religious claims. Thus we have different religious perspectives such as Hinduism, Buddhism, Judaism, Christianity, and Islam (among many others) which are geographically and historical situated such that the dominant cultural concepts and social priorities end up influencing how each understands the divine. Looked at one way, Hick's line can seem correct: a pluralist picture, where each religious tradition is accurately (if incompletely) referring to some core features of supernatural reality while also reflecting varying cultural concepts, can look like a better explanation of religious diversity than a particularist exclusivism on which only one religion is the most accurate account of the supernatural. But on the assumption that this pluralist picture is correct, it raises many questions: one such question is why, if pluralism is correct, it is rarely a part of the doctrine of so many religions. If pluralism gains some support from the fact of religious diversity, it also seems at a loss to explain why so few religions have been tolerant enough to allow such diversity.

Plantinga (1995) argues forcefully that the fact of religious diversity, and the pluralist's handling of it, need not make a religious exclusivist suspect that their own religious beliefs suffer from any irrationality or epistemic defect. Yet he allows that acknowledging the diversity of religious perspectives could (though might not) defeat the knowledge which the believer might otherwise have had in the absence of such acknowledgment (1995, 214-215), particularly if it leads one to worry that one believes as 
one does largely due to the religious culture into which one was born. ${ }^{16}$ In this way, knowing more about diversity may lead to less religious knowledge, at least in the short run. Yet again, much will depend on the method by which one gained such knowledge (if knowledge it is) in the first place. If one has in fact gained knowledge of theism by direct acquaintance with the truth of theism (either by apprehending the soundness of an ontological proof, or by perceptual acquaintance with God), it is entirely unclear why acknowledging disagreement must undermine that knowledge. ${ }^{17}$

In what remains, I shall briefly consider two arguments concerning religious agreement and disagreement which I think deserve further attention. The first, discussed by Kelly (2011) and Zagzebski (2012, 185ff.), is the "common consent" (consensus gentium) argument for the existence of God. The second argument, put forth by Thurow (2012), is that religious disagreement can actually aid the case for theism, for it might, given an Equal Weight View, rationally require us to end up agreeing on theism. It would seem on a first pass that a theist could not appeal to both arguments on behalf of their view, for one depends on widespread agreement about theism, whereas the other depends on widespread disagreement. But as it happens, these two arguments are not incompatible with each other.

Common consent arguments, in their most modest versions, appeal to the large number of people ${ }^{18}$ who believe that $p$, and then suggest that this common consent can at least provide significant evidence for $p$. While our focus so far has been on religious disagreement, the common consent arguer aims to capitalize on the widespread popularity-both currently and historically — of theism, in order to claim that, while not decisive, this fact is at least a reason in favor of theism. While treating common consent as evidence for theism might seem implausible, notice that more generally, broad agreement (even if not unanimous consensus) that $p$ arrived at

\footnotetext{
${ }^{16}$ See White 2010 for related issues.

${ }^{17} \mathrm{Cf}$. Bogardus 2013 for similar points. Mutatis mutandis if theism is false and it's possible to know, by "seeing" directly, that theism is false: acknowledging disagreement from theists might not dislodge the atheist's knowledge.

${ }^{18}$ At least a strong supermajority. Kelly 2011, 146, n. 18 cites one sociologist (whose avowed goal is to show that non-belief is more prevalent than typically thought) who estimates that around 88 percent of the global population is theist .
} 
independently provides some evidence in favor of $p$. It does so because the truth of $p$ can figure in the best explanation of how broad agreement would have been reached, at least if there are other plausible assumptions about how so many would have arrived at the belief that $p .{ }^{19}$ However, where people reach agreement that $p$ in dependent fashion (such that their reaching the same conclusion is due to collaboration or external pressure), most will deny that broad agreement is evidence for $p$. Note also that disagreement over $p$, if reached independently, can (if there are sufficiently many on each side) provide reason to suspend judgment: for those who found themselves confident that $p$ (or that not- $p$ ), independently reached disagreement offers higher-order evidence that one misjudged the initial evidence. But disagreement similarly loses its force if one learns that such disagreement arose in dependent fashion. ${ }^{20}$ So common consent arguers for theism will need to make the case for enough independence among the those in broad agreement that theism is true.

Thurow (2012) argues that even given an Equal Weight View, there are some cases of peer disagreement over $p$ which rationally require not suspension of judgment, but that the peers come to agreement that $p$. Such cases can arise when the peers agree on the force of some body of evidence $\mathrm{E}$, but disagree on the force of some larger body of evidence $\mathrm{F}$, where, if they suspend judgment on the force of $\mathrm{F}$, then $\mathrm{E}$ justifies belief in $p$ for each of them. If the peers can resolve their more basic disagreement over F first by weighting their judgments about that proposition equally, ${ }^{21}$ then they should do so (and continue doing) until their agreed upon evidence supports adopting the same attitude toward $p$. Thurow then argues that it is possible to apply such insights, in a Bayesian framework, to how experts disagreeing over the evidence for theism ought to proceed: such peers

\footnotetext{
${ }^{19}$ See Kelly 2011 for thoughtful discussion.

${ }^{20}$ Suppose one learns that ten people believe $p$, while ten believe not- $p$. But one also learns that their beliefs were formed by each telling the next, one by one, what they believe, and they were lined up in such a way that the next listener was always inclined to distrust and believe the negation of what their informant told them. In such a set-up, the existence of such a balanced disagreement would not lead one to revise one's belief, if one believed, that $p$.

${ }^{21}$ Perhaps by Thurow's own 'Straight Averaging Equal Weight' model $(2012,214)$, which aims to capture the spirit of the Equal Weight View.
} 
might diverge over the force of the total evidence, but be rationally required to reconcile their dissent by eventually coming to agreement that theism is true, or that theism is false (which one depends on the details). If Thurow's approach to the Equal Weight View is right, then it may turn out that just learning the probability distribution of these experts can rationally require that we work hard to come (after much honest toil) to agreement over the matter of theism.

If a modest common consent argument has something to be said for it, then we should expect to grant some weight to the fact of widespread agreement in favor of theism. If Thurow is right, and it also is the case that disagreement over theism, among experts, boils down largely to which body of evidence those experts think matters for reaching a conclusion about theism, then such experts will only proceed rationally if they work together to resolve those disagreements and reach a consensus. And a theist might argue along both lines, where her hope is that the latter approach should yield a consensus in favor of theism rather than atheism; in this way, the two arguments are in principle compatible with each other. ${ }^{22}$

Yet the prospects for what each argument can accomplish might seem dim. Any modest evidence gained by a common consent appeal is likely to be swamped by the force of other (first-order) evidence for or against theism. And an approach along Thurow's lines seems hampered by the following facts: (i) dissenting experts typically disagree over what a given body of evidence itself supports (and this can be because they find themselves with different prior probability distributions, or different views of what can count as evidence); and (ii) these experts will have personal and professional reasons for avoiding concession and resolution. ${ }^{23}$

${ }^{22}$ Note that someone wanting to use both arguments needn't deny the plausible idea, grounded in the probability calculus, that a proposition $p$ is only evidence for some hypothesis $\mathrm{H}$ just in case $\neg p$ is evidence against $\mathrm{H}$. For the common consent argument appeals to widespread agreement among all manner of people, whereas Thurow's Equal Weight view appeals only to the disagreement among various peer experts.

${ }^{23}$ And (iii) to undertake the project, one would need a vast sociological study to determine who should be the selected experts, and then what their degrees of belief are concerning (say) the probability that miracles have occurred, or the probability of theism given the horrendous evils in our world. 


\section{Conclusion}

Where does all this leave us? We have surveyed the general issues arising from the debates over the epistemology of disagreement, and considered how some of those points carry over to religious epistemology and religious diversity. In doing so, we have had to acknowledge the problems arising from the meta-level disagreements among philosophers over how best to deal with disagreement and the assessment of peer-hood, and over what counts as evidence (of varying strengths) in the religious domain, how easily one could come to know truths concerning matters of religion, and whether testimony or perception or some other method of forming beliefs would put one in an adequate position to believe even while acknowledging disagreements. Even if epistemologists unanimously agreed on some of the broader issues concerning the nature of evidence, how to handle higher-order evidence, or the conditions for acquiring knowledge through testimony, things would only be slightly improved; because there would remain disagreement about, for example, how and when those insights apply in religion, about when epistemic humility is a virtue rather than a vice in matters of religion, and how (if at all) moral and spiritual considerations come into play. Learning to live with such disagreement is a part of the challenge. ${ }^{24}$

Seattle Pacific University

\section{References}

Alston, William P. 1991. Perceiving God: The Epistemology of Religious Experience. Ithaca: Cornell University Press.

Baker-Hytch, Max. 2018. "Testimony Amidst Diversity." In Matthew A. Benton, John Hawthorne, and Dani Rabinowitz (eds.), Knowledge, Belief, and God: New Insights in Religious Epistemology. Oxford: Oxford University Press.

\footnotetext{
${ }^{24}$ Many thanks to Nathan King, Patrick McDonald, John Pittard, Rebekah Rice, Leland Saunders, and Kelly Weirich for helpful comments.
} 
Baker-Hytch, Max and Benton, Matthew A. 2015. "Defeatism Defeated." Philosophical Perspectives 29: 40-66.

Benton, Matthew A. 2016. "Knowledge and Evidence You Should Have Had." Episteme 13: 471-479.

Benton, Matthew A., Hawthorne, John, and Rabinowitz, Dani (eds.). 2018. Knowledge, Belief, and God: New Insights in Religious Epistemology. Oxford: Oxford University Press.

Bogardus, Tomas. 2013. "Disagreeing with the (Religious) Skeptic." International Journal for Philosophy of Religion 74: 5-17.

Christensen, David. 2007. "Epistemology of Disagreement: The Good News." The Philosophical Review 116: 187-217.

Christensen, David. 2016. "Conciliation, Uniqueness, and Rational Toxicity." Noûs 50: 584-6o3.

Christensen, David and Lackey, Jennifer (eds.). 2013. The Epistemology of Disagreement: New Essays. Oxford: Oxford University Press.

Cohen, Stewart. 2013. "A Defense of the (Almost) Equal Weight View." In David Christensen and Jennifer Lackey (eds.), The Epistemology of Disagreement: New Essays, 98-117. Oxford: Oxford University Press.

Elga, Adam. 2007. "Reflection and Disagreement." Noûs 48: 478-502.

Elga, Adam. 2010. "How to Disagree about How to Disagree." In Richard Feldman and Ted A. Warfield (eds.), Disagreement, 175-186. Oxford: Oxford University Press.

Feldman, Richard. 2006. "Epistemological Puzzles about Disagreement." In Stephen Hetherington (ed.), Epistemology Futures. Oxford: Oxford University Press.

Feldman, Richard. 2007. "Reasonable Religious Disagreements." In Louise Antony (ed.), Philosophers without Gods. Oxford: Oxford University Press. 
Feldman, Richard. 2014. "Evidence of Evidence is Evidence." In Jonathan Matheson and Rico Vitz (eds.), The Ethics of Belief, 284-30o. Oxford: Oxford University Press.

Feldman, Richard and Warfield, Ted A. (eds.). 2010. Disagreement. Oxford: Oxford University Press.

Fitelson, Branden. 2012. "Evidence of Evidence is Not (Necessarily) Evidence." Analysis 72: 85-88.

Goldberg, Sanford C. 2013. "Disagreement, Defeat, and Assertion." In David Christensen and Jennifer Lackey (eds.), The Epistemology of Disagreement: New Essays. Oxford: Oxford University Press.

Goldberg, Sanford C. 2014. "Does Externalist Episemology Rationalize Religious Commitment?" In Laura Frances Callahan and Timothy O'Connor (eds.), Religious Faith and Intellectual Virtue, 279-298. Oxford University Press.

Goldberg, Sanford C. 2015. Assertion: On the Philosophical Significance of Assertoric Speech. Oxford: Oxford University Press.

Goldberg, Sanford C. 2016. "On the Epistemic Significance of Evidence You Should Have Had." Episteme 13: 449-470.

Gutting, Gary. 1982. Religious Belief and Religious Skepticism. Notre Dame, IN: University of Notre Dame Press.

Hawthorne, John and Srinivasan, Amia. 2013. "Disagreement Without Transparency: Some Bleak Thoughts.” In David Christensen and Jennifer Lackey (eds.), The Epistemology of Disagreement: New Essays, 9-30. Oxford: Oxford University Press.

Hick, John. 2004. An Interpretation of Religion: Human Responses to the Transcendent. New Haven: Yale University Press, 2nd edition.

Kelly, Thomas. 2005. "The Epistemic Significance of Disagreement." In Tamar Szabò Gendler and John Hawthorne (eds.), Oxford Studies in Epistemology, volume 1. Oxford: Clarendon Press. 
Kelly, Thomas. 2010. "Peer Disagreement and Higher-Order Evidence." In Richard Feldman and Ted A. Warfield (eds.), Disagreement. Oxford: Oxford University Press.

Kelly, Thomas. 2011. "Consensus Gentium: Reflections on the 'Common Consent' Argument for the Existence of God.” In Kelly James Clark and Raymond J. VanArragon (eds.), Evidence and Religious Belief, 135-156. Oxford: Oxford University Press.

King, Nathan L. 2008. "Religious Diversity and its Challenges to Religious Belief." Philosophy Compass 3: 830-853.

King, Nathan L. 2012. "Disagreement: What's the Problem? Or, a Good Peer is Hard to Find." Philosophy and Phenomenological Research 85: 249-272.

Lackey, Jennifer. 2014. “Taking Religious Disagreement Seriously.” In Laura Frances Callahan and Timothy O'Connor (eds.), Religious Faith and Intellectual Virtue, 299-316. Oxford University Press.

Lackey, Jennifer. 2018. "Experts and Peer Disagreement." In Matthew A. Benton, John Hawthorne, and Dani Rabinowitz (eds.), Knowledge, Belief, and God: New Insights in Religious Epistemology. Oxford: Oxford University Press.

Lasonen-Aarnio, Maria. 2010. “Unreasonable Knowledge.” Philosophical Perspectives 24: 1-21.

Matheson, Jonathan D. 2014. "Phenomenal Conservatism and Skeptical Theism." In Trent Dougherty and Justin P. McBrayer (eds.), Skeptical Theism: New Essays, 3-20. Oxford: Oxford University Press.

Pittard, John. 2015a. "Religious Disagreement." Internet Encyclopedia of Philosophy, ISSN 2161-0002, http://www.iep.utm.edu/rel-disa/.

Pittard, John. 2015b. "Resolute Conciliationism." Philosophical Quarterly 65: $442-463$.

Plantinga, Alvin. 1995. "Pluralism: A Defense of Religious Exclusivism." In Thomas D. Senor (ed.), The Rationality of Belief and the Plurality of Faith, 191-215. Ithaca: Cornell University Press. 
Rosen, Gideon. 2001. "Nominalism, Naturalism, and Epistemic Relativism." Philosophical Perspectives 15: 69-91.

Schoenfield, Miriam. 2014. "Permission to Believe: Why Permissivism is True and What It Tells Us About Irrelevant Influences on Belief." Noûs 48: 193-218.

Thurow, Joshua C. 2012. "Does Religious Disagreement Actually Aid the Case for Theism?" In Jake Chandler and Victoria S. Harrison (eds.), Probability in the Philosophy of Religion, 209-224. Oxford University Press.

van Inwagen, Peter. 1994. "Quam Dilecta." In Thomas V. Morris (ed.), God and the Philosophers, 31-6o. Oxford University Press.

van Inwagen, Peter. 1996. "It is Wrong, Everywhere, Always, and for Anyone, to Believe Anything upon Insufficient Evidence." In Jeff Jordan and Daniel Howard-Snyder (eds.), Faith, Freedom, and Rationality: Essays in the Philosophy of Religion, 137-153. Lanham: Rowman \& Littlefield.

White, Roger. 2005. "Epistemic Permissiveness.” Philosophical Perspectives 19: $445-459$.

White, Roger. 2010. "You Just Believe That Because..." Philosophical Perspectives 24: 573-615.

White, Roger. 2018. "Reasoning with Plenitude." In Matthew A. Benton, John Hawthorne, and Dani Rabinowitz (eds.), Knowledge, Belief, and God: New Insights in Religious Epistemology. Oxford: Oxford University Press.

Williamson, Timothy. 2000. Knowledge and its Limits. Oxford: Oxford University Press.

Zagzebski, Linda Trinkaus. 2012. Epistemic Authority: A Theory of Trust, Authority, and Autonomy in Belief. Oxford: Oxford University Press.

\section{Further Reading}

Audi, Robert. 2014. "Normative Disagreement as a Challenge to Moral Philosophy and Philosophical Theology." In Michael Bergmann and Patrick 
Kain (eds.), Challenges to Moral and Religious Belief: Disagreement and Evolution, 61-79. Oxford University Press.

Benton, Matthew A. and Jonathan L. Kvanvig (eds.). Forthcoming. Religious Disagreement and Pluralism. Oxford University Press.

Byrne, Peter. 2004. "It Is Not Reasonable to Believe that Only One Religion Is True." In Michael L. Peterson and Raymond J. VanArragon (eds.), Contemporary Debates in Philosophy of Religion, 201-210, and 215-217. Blackwell Publishing.

DeCruz, Helen. 2017. "Religious Disagreement: An Empirical Study Among Academic Philosophers." Episteme 14: 71-87.

Feldman, Richard. 2003. "Plantinga on Exclusivism." Faith and Philosophy 20: $85-90$.

Kraft, James. 2012. The Epistemology of Religious Disagreement: A Better Understanding. Palgrave Macmillan.

Pittard, John. 2014. "Conciliationism and Religious Disagreement." In Michael Bergmann and Patrick Kain (eds.), Challenges to Moral and Religious Belief: Disagreement and Evolution, 80-97. Oxford University Press.

van Inwagen, Peter. 2010. "We're Right. They're Wrong." In Richard Feldman and Ted A. Warfield (eds.), Disagreement, 10-28. Oxford University Press.

Wolterstorff, Nicholas. 2014. "The Significance of Inexplicable Disagreement." In Laura Frances Callahan and Timothy O'Connor (eds.), Religious Faith and Intellectual Virtue, 317-330. Oxford University Press.

Yandell, Keith E. 2004. "How to Sink in Cognitive Quicksand: Nuancing Religious Pluralism." In Michael L. Peterson and Raymond J. VanArragon (eds.), Contemporary Debates in Philosophy of Religion, 191-200, and 211-214. Blackwell Publishing. 